\title{
Strategic drivers for the development of innovative methods of financial management in Russian industrial organizations
}

\author{
Nadezhda Piontkevich \\ Ural State University of Economics, 8 Marta Str., 62, 620144 Ekaterinburg, Russia
}

\begin{abstract}
The modern world economy faces the objective need to build a multipolar world. This is accompanied by increasing geopolitical instability, unsustainable development of the world economy and sharp aggravation of the global competition. In these conditions, the strategic guidelines for global economic development were exposed to external challenges that had an impact on all the leading national economies and the world business community as a whole. The purpose of the article is to study modern strategic drivers of development in the financial management system of industrial organizations in various sectors of economy. The article uses modern methods of collecting and processing initial information. The authors defined the main strategic directions for sustainable development of industrial organizations in modern conditions. The article proves the prospects of using the identified strategic drivers for the development of innovative methods in financial management in Russian industrial organizations.
\end{abstract}

\section{Introduction}

Instability of macroeconomic processes and inaccuracies in measuring the influence of factors of economic growth of business entities [16, p. 140-161; 15, p. 27] require all levels of management of the national economy (from the state as a whole to a separate economic entity) to develop and immediately implement a comprehensive plan of effective urgent measures for overcoming the crisis.

Promoting the national interests of the Russian Federation in the economic sphere should be ensured both through implementing the complex of the above-mentioned macro-measures, and through a well-organized business by creating conditions for satisfying the interests of all its stakeholders within each individual economic entity that forms the national gross domestic product. Sustainable development of business entities largely depends on the internal potential of the entities themselves and the development of their communications environment $[18 ; 19]$.

\section{Materials and methods}

The article uses a set of basic research methods, namely: scientific abstraction, logical, dialectical, comparative analysis, the method of expert assessments, economic and 
mathematical methods, and dynamic methods. The experimental study base is the data from the Federal State Statistics Service (Rosstat).

The methodological basis for the formation and application of innovative methods of financial management of an organization influenced by internal and external factors as any organization's basic functional activity, according to the author, are the following strategic drivers for Russian economic development:

- The strategy of economic security of the Russian Federation until 2030 [7];

- "The concept of sustainable development", adopted at the UN conference on development and environment in Rio de Janeiro in 1992 [8];

- The sixth post-industrial technological order;

- The fourth industrial revolution Industry 4.0.

\section{Results and discussion}

In the modern geo-economic space, all these strategic drivers combine innovative trends in the global economic development [12, pp.114; 117-118]. The innovative activity of organizations is of particular importance in strengthening the national economy in modern conditions [17].

Foreign scholars Eugene F. Brigham and Michael C. Ehrhardt note that according to the results of a poll conducted by Fortune magazine in 2001 among more than 10 thousand directors of large companies, the first most important indicator for assessing management effectiveness is "the ability to innovate." [1, p. 25].

Russian professor O.S. Sukharev considers science as the most important factor contributing to the formation of "competitive means of production in the long term" $[10, p$. 430].

The results of the author's study of the dynamics of investment in technological innovations (product, process) by types of innovative activities of Russian organizations for the period 2015-2019. are presented in Figure 1. 


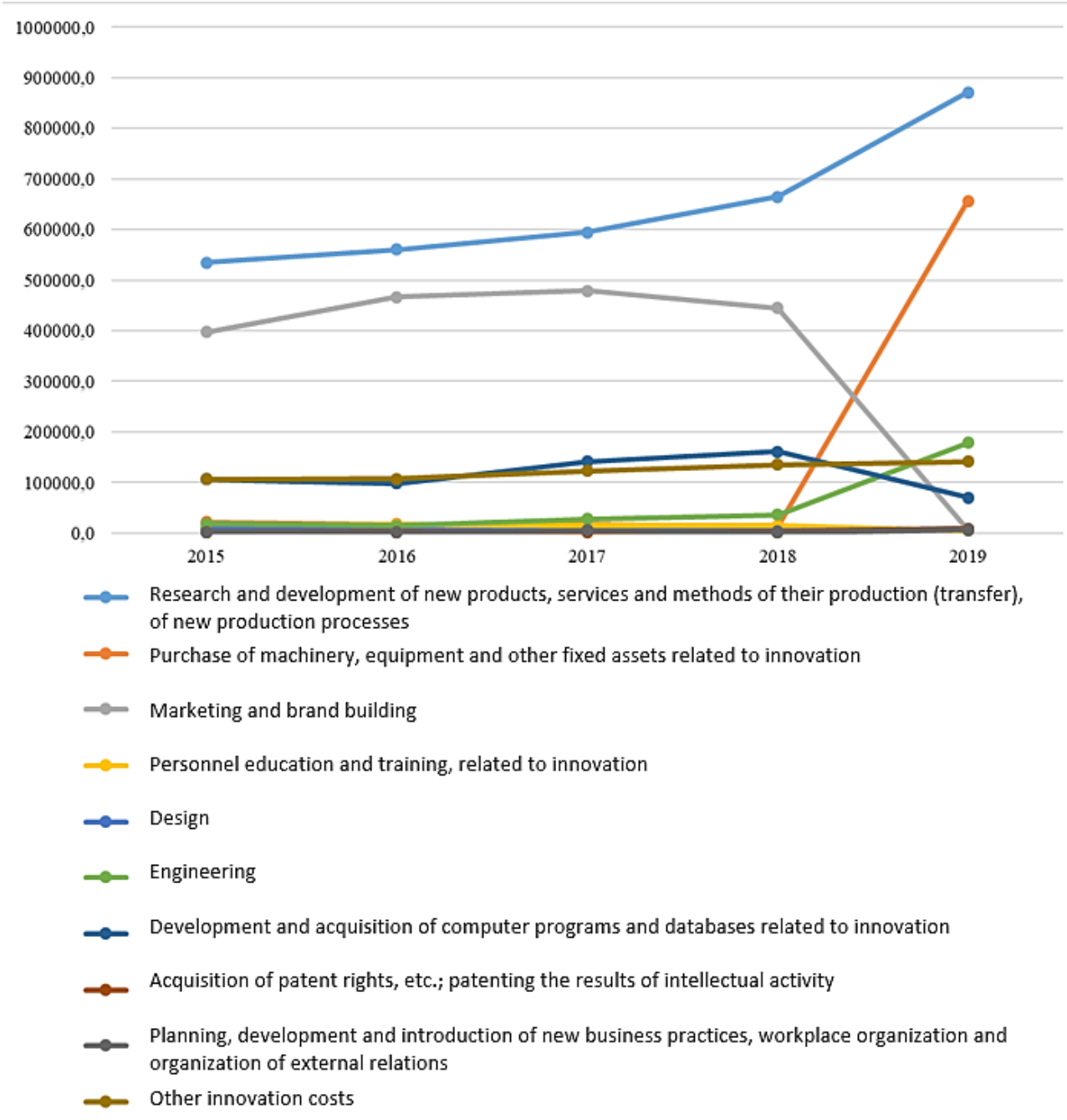

Fig. 1. Dynamics of total (capital and current) costs of technological (product, process) innovations by types of innovation activities in the Russian Federation in 2015-2019,\% Source: compiled by the author based on: [13].

Almost half (over 44\%) of all the technological innovations in the analyzed period are research and development of new products; During this period, the significance of the cost of purchasing machinery associated with innovation increased exponentially - from $1.77 \%$ to $33.62 \%$ (Figure 2).

Total (capital and current) costs of innovation in the Russian Federation for the period of 2015-2019 increased by $61.28 \%$, including:

- research and development of new products - by $62.98 \%$;

- purchasing machines related to innovative activities - 30 times;

- engineering - 9.7 times;

- acquisition of rights to patents, etc. - 4.8 times;

- planning, developing and implementing new business methods - 2.5 times.

At the micro level, an organization's innovative activity creates additional competitive advantages for the business. 


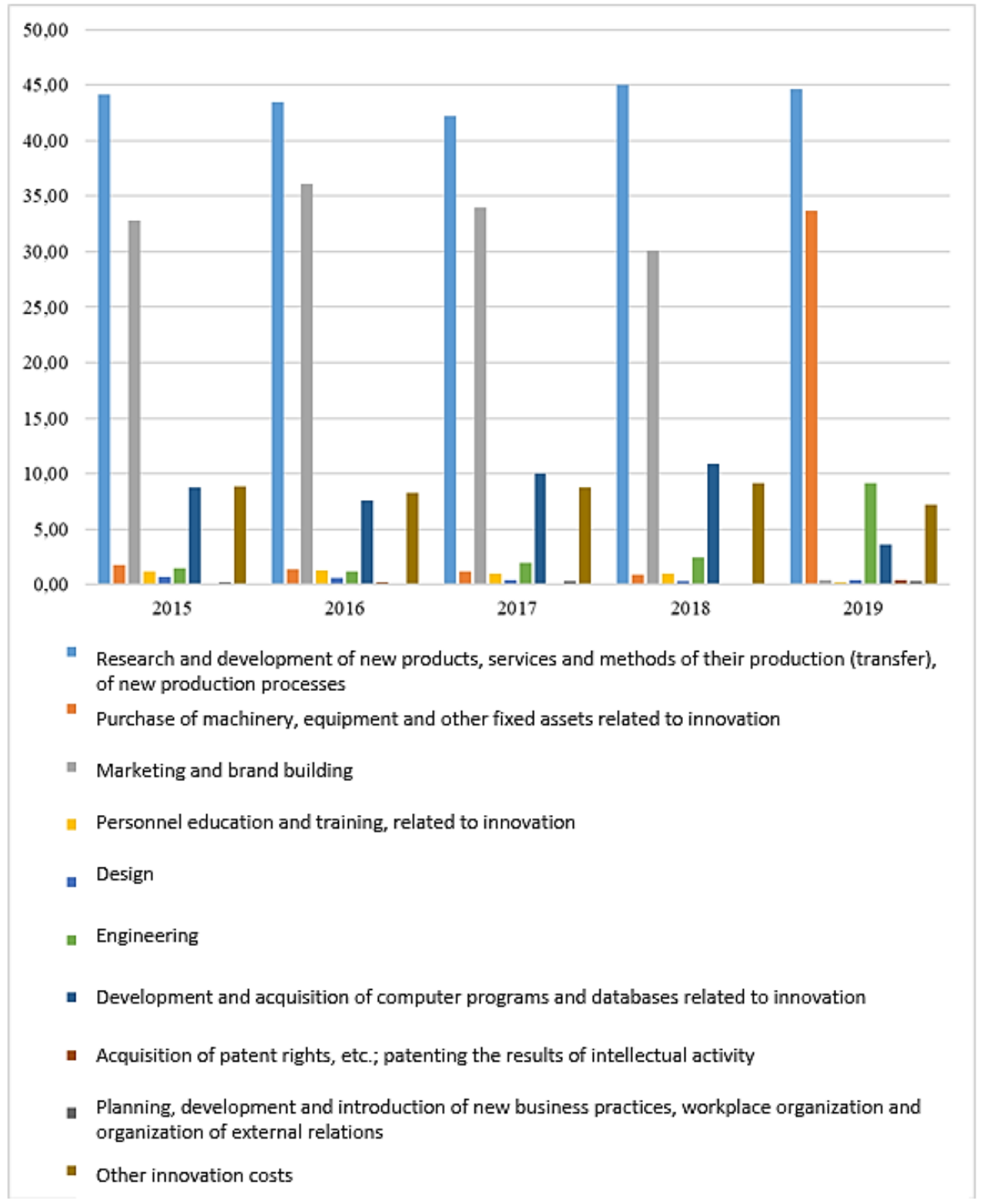

Fig. 2. The structure of total (capital and current) costs of technological (product, process) innovations by types of innovation activities in the Russian Federation in 2015-2019,\% Source: compiled by the author based on: [13].

Let's define the role of each strategic driver in increasing the sustainability of industrial organizations.

1 st strategic driver "Strategy of economic security of the Russian Federation until 2030" is proposed to be applied in the financial management of an organization influenced by internal and external factors. It is to be applied by developing innovative methods through studying the following indicators of the country's economic security: the index of the physical volume of the gross domestic product; the index of entrepreneurial confidence of manufacturing enterprises, etc. 
The second strategic driver is the "UN Sustainable Development Concept" (World Commission on Environment and Development, 1987), which has become the guiding principle for long-term global development. Sustainable development for the period 20162030 presupposes achieving three fundamental goals: economic and social progress and environmental protection [2].

The indicators of the driver, according to the author, are the following UN sustainable development goals:

- N 8 "Foster sustained, inclusive and sustainable economic growth, full and productive employment and decent work for all" (priority -social-environmental);

- N 9 "Build resilient infrastructure, promoting inclusive and sustainable industrialization and foster innovation" (priority - economic);

- N 12 "Ensure sustainable consumption and production patterns" (priority - social environmental - economic);

- N 17 "Strengthen the means of implementation and revitalize the global partnership for sustainable development (priority - social and economic) [3, p. 9].

The third strategic driver "The sixth post-industrial technological order" in the financial management of an organization under the influence of internal and external factors is proposed to be applied through the development of innovative methods by using a complex of breakthrough technologies as an indicator, declared at the International Forum on Technological Development "TECHNOPROM-2013" [4].

For organizations, a new technological order creates conditions (opportunities) for using modern technologies in business and implementing innovative methods of financial management under the influence of internal and external factors to ensure sustainable development of business entities in interrelation and consistency with the outside world. In 2020, quantitative changes in the field of technology - the forced massive introduction of advanced solutions by businesses and government agencies led to qualitative changes. A new technological order, with the widespread use of cyber-physical systems, set in, this is the conclusion made by the participants of the public talk "Technological progress - 2020 and business development" held by RBC Petersburg within the project «Energetic people. Heroes of the Year"[6]

The 4th strategic driver "The fourth industrial revolution Industry 4.0 " represents "the beginning of the secondary modernization of the economy within the VI post-industrial technological order" [5, p. 9], associated with the massive introduction of cyber-physical systems in the production and human needs service. As noted by the scientists of the Institute of Economics of the Ural Branch of the Russian Academy of Sciences, "in the world, the main concept of industrial development today is a phenomenon called" Industry 4.0", which is directly related to the concepts of" digitalization "and" digital production "” [9, p. 162]. As a result, Industry 4.0 entails risks of increasing instability, and therefore its onset is perceived as a challenge to which humanity has to respond [14].

Foreign scientists Eugene F. Brigham and Michael C. Ehrhardt have similar views on the impact of new technologies on economic development: such areas of analysis as the study of globalization processes and the active use of information technologies in business are becoming increasingly important. According to the scientists, the indicated tendencies can bring a business to a higher level of profitability, provided that risks are reduced, but at the same time, there is an increase in competition and the emergence of "new, previously unknown sources of risks" [1, p. 41]. 


\section{Conclusion}

According to Professor S.A. Tolkachyov, the transition to neo-industrial development is associated with various potential risks associated with transition to a pseudo-market model, increasing unemployment, etc. [11].

In relation to this study, it is proposed to apply the following features of Industry 4.0 information systems as the indicators of the strategic driver "Industry 4.0" in the organization's financial management under the influence of internal and external factors:

- extreme productivity, which can be achieved through the use of modern computer technologies (multi-core processors, computing in memory, SSD, cloud spaces, big data analytics, etc.);

- extreme automation, which involves the use of artificial intelligence methods in all the spheres of human activity - in business, in public administration, in private life;

- extreme connectivity, which determines the conditions for breaking down distance, time or some other barriers limiting interactions between people and machines, people and people, machines and machines[14].

The result of the study of the influence of strategic drivers on the development of innovative methods of financial management in Russian industrial organizations is the creation of surplus value at the level of the latter in the process of using financial and nonfinancial resources as a source of meeting the interests of external and internal subjects.

\section{References}

1. J. Brigham, Financial management, 960 (2007)

2. UN General Assembly. Chairman of the 65th session, https://www.un.org/

3. Report on human development in the Russian Federation for 2016, 298 (2016)

4. Infographics about technological structures. International Forum of Technological Development "TECHNOPROM-2013", http:/forumtechnoprom.com/

5. L.A. Mochalova, Journal of New Economy, 21(4), 5 (2020)

6. "Our time has come": how a new technological order is being created. RBC. Business information space, https://www.rbc.ru/

7. "On the Strategy of Economic Security of the Russian Federation for the Period up to 2030" Decree of the President of the Russian Federation of May 13, 208 (2017)

8. United Nations Organization: Peace, Dignity and Equality on a Healthy Planet, https://www.un.org/ru/

9. Strategic directions and priorities of regional development in the context of global challenges, Yekaterinburg: Ural Branch of the Russian Academy of Sciences, 504 (2019)

10. O.S. Sukharev, Institutional theory and economic policy: Towards a new theory of the transmission mechanism in macroeconomics, 804 (2007)

11. S.A. Tolkachev, Conditions and factors of neo-industrial development. Presentation of the results of research work, http://www.fa.ru/

12. L.A. Tretyak, E.M. Dushevina, Innovative Economy: Prospects for Development and Improvement, 5(10), 114 (2015)

13. Federal State Statistics Service (Rosstat), https://rosstat.gov.ru

14. The fourth industrial revolution. Popular about the main technological trend of the XXI century. TAdviser (Russian Internet portal and analytical agency), https://www.tadviser.ru/ 
15. J. Bailey Martin, The Mismeasurement of Economic Growth, 27 (1991)

16. R Connolly, D Dubofsky, Ch. Stivers, Journal of Empirical Finance, 48, 140 (2018)

17. V.F. Grankin, Messenger of The Kursk state agricultural academy, 4, 66 (2017)

18. Mark J. Flannerya, Kristine Watson Hankins, Journal of Corporate Finance, 19, 1 (2013)

19. Peter Benczur, Stelios Karagiannis, Virmantas Kvedaras, Journal of Macroeconomics (2018) 